\title{
In Vitro Investigation on Phenolic Compound and Antioxidant Activities from Methanolic Extracts of Black Soybean Seed
}

\author{
Muchdar Soedarjo* \\ Indonesian Legume and Tuber crops Research Institute, P.O. Box 66, Km 8, Malang, East Java, Indonesia
} 65101

*Corresponding Author: Muchdar Soedarjo, Indonesian Legume and Tuber crops Research Institute, P.O. Box 66, Km 8, Malang, East Java, Indonesia 65101, Email: muchdar.soedarjo62@gmail.com

\begin{abstract}
Tempe, tofu and soy sauce are the main products of soybean commonly consumed in the daily food for the people of Indonesia. Due to its high protein content and the presence of significant antioxidant activities, soybean is considered as functional food. Antioxidant could improve and maintain human health due to its ability to nullify the negative effect of reactive oxygen. The present study was carried out to evaluate total phenolic content and antioxidant activities of some Indonesian black soybean seeds. Observation was done in three replicates and standard deviation was made. The results of the present study showed a variability of total phenolic content and antioxidant activities among the black soybean seeds tested. The soybean variety Detam 2 revealed the highest phenolic content and antioxidant activities as measured with ABTS and DPPH methods. Antioxidant activity of black soybean seeds was highly correlated to total phenolic content. Thus, phenolic content could be used as a good indicator of soybean high in antioxidant. In all black soybean varieties tested, antioxidant activity was found to be mainly located in the seed coat.
\end{abstract}

Keywords: Black soybean, seed coat, phenolic, antioxidant

\section{INTRODUCTION}

Indonesia always imports soybean annually to meet a demand for food industries, namely tempe, tofu and soy sauce. For example, Indonesia imported 2.26 million ton soybean in 2015 which is equivalent to US\$ 1.03 million (Kompas 2016). A significant decrease of national soybean production is caused by unfavorable price of soybean seed. Under such undesirable condition for growing soybean, farmers shift to grow other crops, such as corn and horticultural crops. An increase of soybean price to meet the benefit of the farmers and consumers would drive the farmers' motivation to grow soybean in a larger area. In such circumtances, it is expected to increase the National soybean production.

Japanese government subsidizes soybean price to farmers as much as 11,310 yen/60 kg soybean (Yusman 2017) in order to motivate farmers growing soybean. However, this strategy seems to be unlikely to happen in Indonesia. It seems to be possible to increase the domestic soybean price through better awareness and understanding of the Indonesian people that soybean seeds generated by a conventional breeding is safer and better to be consumed. In addition to high protein content, soybean produces secondary metabolites playing a role as antioxidant (Wu et al. 2009; Doss et al. 2011; Mujić et al. 2011; Sefatie et al. 2013; Pertiwi and Nurhidayah 2013).An intake of soybean would likely to improve antioxidant state in human body (Bakhtiari et al. 2019). The ample amount of antioxidant in human body is required to negate the excessive amount of reactive oxygen which is harmful to human health. Our conventionally bred soybean, yellow seed coat, was reported to possess significantly higher antioxidant activity than imported soybean (Soedarjo et al. 2019). These reasonings should be disseminated to the people to acquire a special appreciation. Such a perception could hopefully trigger the people to purchase soybean seeds obtained from conventional breeding with relatively higher price benefitting to soybean growers. As a result, farmers will grow soybean on much larger area and the National soybean production will significantly increase, consequently.

Other than yellow soybean seeds, Indonesian Legume and Tuber Crops Research Institute (ILeTRI), has released some black soybean varieties, Detam 1, Detam 2, Detam 3 and Detam 4 (ILeTRI 2016). Researchers (Takahashi et al. 2005; Ţilić et al. 2011; Malencic et al. 2012; Dajanta et al. 2013; 
In Vitro Investigation on Phenolic Compound and Antioxidant Activities from Methanolic Extracts of Black Soybean Seed

Yusnawan 2016) have revealed higher antioxidant activity of black soybean seed than yellow soybean seed. Indeed, our black soybean seeds have also been assayed to show higher antioxidant activities than the yellow soybean varieties (Yusnawan 2016). However, it has not been investigated where the antioxidant activity is mainly concentrated, in the seed coat or in the cotyledon of the soybean seed. The present research work was carried out to evaluate the phenolic content and the degree of antioxidant activities on the seed coat and the cotyledon of black soybean seeds.

\section{Materials AND Method}

The present laboratory research work was done at the Chemistry laboratory, the Institute of 10 November Surabaya, East Java, Indonesia in 2018-2019. The improved black soybean seeds used in the present work were provided by the Germplasm Division of ILeTRI, The Indonesian Ministry of Agriculture (Table 1 and Figure 1). Beside the whole grain, Detam 1 and Detam 2 were partitioned into seed coat and cotyledon (seed without the seed coat) (Figure 4). Each sample of soybean seed was macerated into powder and extracted with methanol before further use for phenolic and antioxidant evaluation.

Table1. Indonesian improved soybean varieties used in the present research work

\begin{tabular}{|l|l|l|l|l|}
\hline No. & Varieties & Genetic background/breeding & Seed coatcolor & Seed size* \\
\hline 1. & Detam 1 & Introduction line x Kawi & Black & Big \\
\hline 2. & Detam 2 & line 9837 x Wilis & black & Medium \\
\hline 3. & Detam 3 & W 9837 x Cikurai & black & Medium \\
\hline 4. & Detam 4 & W 9837 x G100H & black & Medium \\
\hline 5. & Mallika & Selected from local variety, Central Java, Indonesia & black & Medium \\
\hline
\end{tabular}

* Big: $\geq 14$ g/100 seeds, Medium: 10-14 g/100 seeds
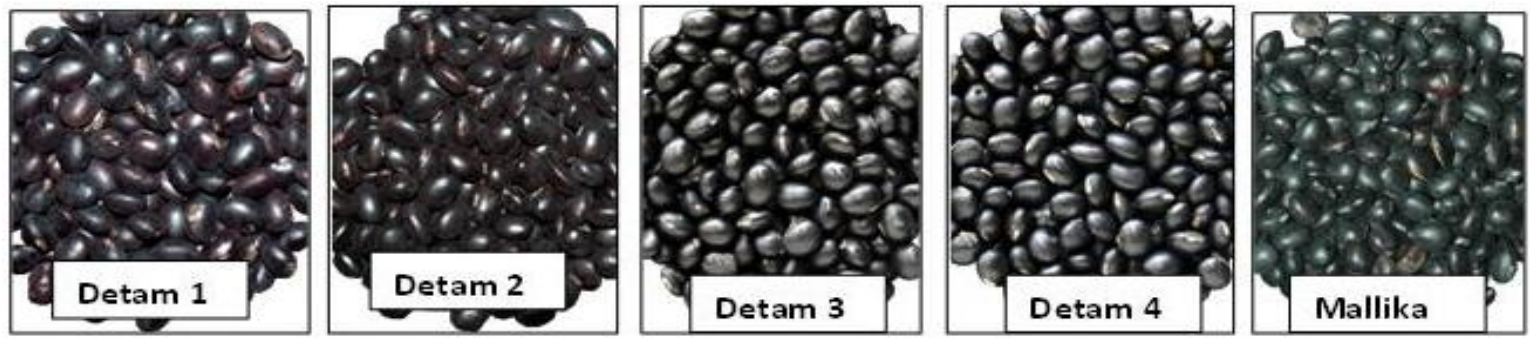

Figure1. The performance of black soybean varieties used in the current study

\subsection{Determination of Total Phenolic Compound}

The powder of each soybean samples was dissolved into methanol to reach a final concentration of 1 $\mathrm{mg} / \mathrm{ml}$ and was considered as a sample. Sixty six microliter of each sample and $500 \mu \mathrm{l}$ reagent of 10 $\%$ Folin was mixed thoroughly. Afterwards, the mixture was incubated in the dark room for 5 minutes. After incubation, the mixture was added with $500 \mu 1$ of $6 \% \mathrm{Na} 2 \mathrm{CO} 3$ and was stirred thoroughly. The mixture was further incubated in the dark room for 90 minutes. Finally, each sample was determined by spectrophotometer at $\lambda 750 \mathrm{~nm}$. Measurement of each sample was done 3 times and was presented as mg GAE/g sample (Qassabi et al. 2018).

\subsection{Determination of Antioxidant Activity by ABTS}

Free radical solution of ABTS (2,2'-azino-bis (3-ethylbenzothiazoline-6-sulfonic acid) was prepared by mixing $5 \mathrm{ml}$ of $7 \mathrm{mM} \mathrm{ABTS}$ and $88 \mu \mathrm{l}$ of $140 \mathrm{mM} \mathrm{K2S2O} 8$ (Putri et al. 2018). This Free radical solution was incubated in the dark room at room temperature for 16 hours. Afterwards, $300 \mathrm{ml}$ ethanol was added into the free radical solution in order to reach absorbance of $0.7 \pm 0.02$ unit at $\lambda$ $734 \mathrm{~nm}$. The sample solution consisting of $10 \mu \mathrm{l}$ sample (10 mg sample/ml DMSO) and $1 \mathrm{ml}$ of ABTS free radical solution was incubated for four minutes at room temperature. Furthermore, the sample solution (As) was measured by UV-Vis spectrophotometer at $\lambda 734 \mathrm{~nm}$. Trolox (6-hydroxy2,5,7,8-tetramethylchroman-2-carboxylic acid) was used as a positive control. DMSO was used as a negative control or blank $(\mathrm{Ab})$. Each sample was measured three times and standard deviation was calculated based on the three replicates. The inhibitory activity was measured by formula (1).

Inhibitory activity $(\%)=[(\mathrm{Ab}-\mathrm{As}) / \mathrm{Ab}] \times 100 \%$ 
In Vitro Investigation on Phenolic Compound and Antioxidant Activities from Methanolic Extracts of Black Soybean Seed

\subsection{Determination of Antioxidant Activity by DPPH}

Antioxidant activity was measured by employing the method of Brand Williams et al.(1995) after slightly modification by Dudonne et al. (2009).The methanolic extracts of soybean seeds was dissolved in methanol (analytical grade) to maximum concentration. A DPPH solution (2,2-diphenyl2-picrylhydrazyl hydrate) was dissolved in methanol to a final concentration of $6 \times 10^{-5} \mathrm{M}$. Extract of each sample $(33.3 \mathrm{ml})$ was poured into a test tube containing $1 \mathrm{ml} \mathrm{DPPH}$, the mixture was stirred thoroughly and was named as 'As'. The negative control consists of $33.3 \mathrm{ml}$ methanol and was thoroughly mixed with $1 \mathrm{ml}$ DPPH in a test tube and this mixture was named as 'Ab'. Gallic acid was used as positive control. The mixture of all samples (As) and the mixture of the negative control (Ab) were incubated at room temperature for 20 minutes. Right after the incubation, the absorbance of the mixture of each sample (As) and the mixture of $A b$ were read with a spectrophotometer at $515 \mathrm{~nm}$. The reading was done at three replicates for each sample and standard deviation was calculated based on the three replicates. The degree of antioxidant activity was calculated as formula 1 .

\section{RESULTS AND DISCUSSION}

\subsection{Total Phenolic Content}

Total phenolic content among Indonesian black soybean seeds varied significantly (Figure2). The highest total phenolic content was observed on the seed of soybean var. Detam $2(25.94 \mathrm{~g} \mathrm{GAE} / \mathrm{g})$. Soybean var. Detam 1contains the lowest total phenolic content, i.e.,4.51 mg GAE/g which is significantly lower compared to phenolic content of Detam 2, Detam 3, Detam 4 and Mallica. Whilst, the phenolic contents of Detam 3, Detam 4 and Mallica were comparable. Black soybean seed has been reported to be related to relatively high phenolic compound and was confirmed to contain higher phenolic content than yellow soybean seed coat (Takahashi et al. 2005; Kumara et al. 2010; Tilić et al. 2011; Malencic et al. 2012; Dajanta et al. 2013; Yusnawan 2016). However, our present results indicate that the black soybean seed does not always

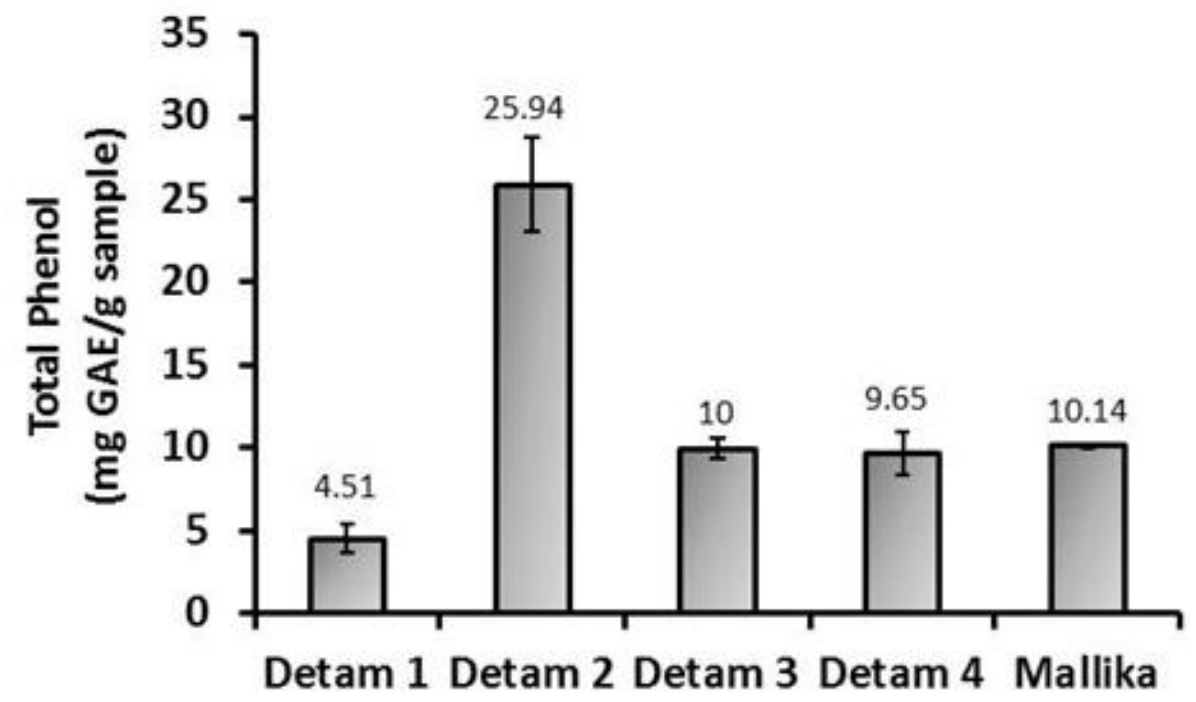

Figure2. Total phenolic content ( $\mathrm{mg}$ GAE/g sampel) of Indonesian improved soybean seeds

possess high phenolic content. Phenolic content of Detam 1 (black soybean seed) was only half of the phenolic content of Indonesian yellow soybean seed, Detap 1 and Demas (Soedarjo et al. 2019). Therefore, the genetics encoding for phenotypes other than the color of the soybean seed coat might also contribute to the phenolic profile.

\subsection{Antioxidant Activity by ABTS and DPPH Methods}

Figure 3 depicted a variability of antioxidant activities among the balck soybean seeds tested as measured by ABTS as well as by DPPH methods. Soybean seed of Detam 2 showed the highest antioxidant activity as measured either with ABTS or DPPH. In contrary, Detam 1 revealed the lowest antioxidant activity, eventhough, the seed coat color is also black. All soybean varieties used in the present research work were generated through a conventional breeding with different genetic backgrounds (see Table 1). The previous findings revealed that different genetic background within 


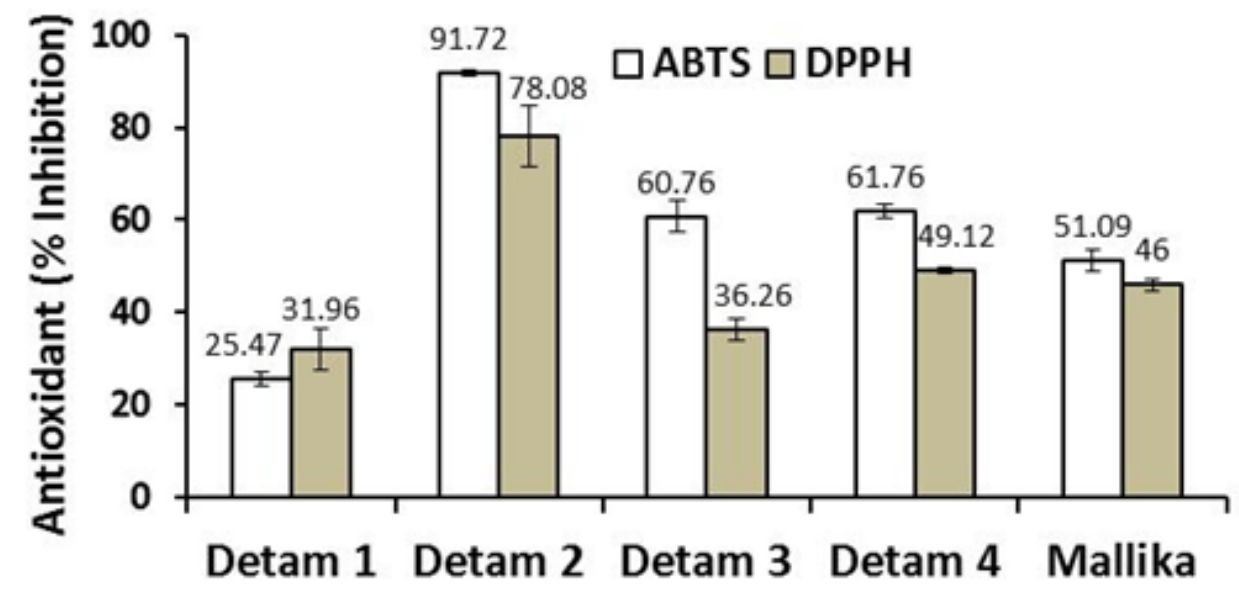

Figure3. Aktivitas antioksidan biji kedelai warna kulit hitam dengan metode ABTS $(99 \mu \mathrm{g} / \mathrm{ml})$ dan DPPH $(619 \mu \mathrm{g} / \mathrm{ml})$ plant species caused a variability of antioxidant measured with ABTS (Mikulajová et al. 2007; Sing et al. 2018). A variability of antioxidant activity within the black soybean varieties was also reported due to different genetic background (Kumara et al. 2010; Lee et al. 2016, Yusnawan 2016). Considering these previous findings and the results of the present research work, it is suggested that genetic background determining the phenotypes other than the genetics for seed coat color seems to play role in the degree of antioxidant activity.

\subsection{Correlation Between Phenolic Compound and Antioxidant Activity}

Correlation value $(\mathrm{r})$ between total phenolic compound and antioxidant activity was found to be highly correlated as measured with ABTS $(r=0.922104459)$ and DPPH $(r=0.961998886)$ methods and is significant at $1 \%$ (Table 2). The result of this correlation analysis suggests that high phenol content of soybean seed will be followed with high antioxidant activity measured with either ABTS or DPPH method. The Present study is in accordance to the research results reported by several researchers who found a positive correlation between total phenol and antioxidant activities in soybean and other plant species (Malenčić et al. 2007; Mikulajová et al. 2007; Stanković 2011; Lee et al. 2014; Nam et al. 2014; Rebaya et al. 2014; Hossain and Shah 2015; Fidrianny et al. 2016; Khalid et al. 2017; Parikh and Patel 2017; Johari and Khong 2019). Therefore, it could be suggested that total phenol is a good initial indicator of antioxidant activities and could be used as an important trait to screen soybean genotypes exerting certain degree of antioxidant activity.

Table2. Correlation analysis between phenolic compound and antioxidant activities within the black soybean seeds.

\begin{tabular}{|c|c|c|}
\hline & Antioxidant by ABTS & Antioxidant by DPPH \\
\hline Total phenol & $\mathrm{r}=0.922104459^{* *}$ & $\mathrm{r}=0.961998886^{* *}$ \\
\hline Note & Highly correlated and significant at F 1\% & Highly correlatedand significant at F 1\% \\
\hline
\end{tabular}

\subsection{Localization of Antioxidant Activities within Soybean Seeds}

The color of cotyledons (seed without seed coat) of all black soybean seed is yellow (figure 4). Yellow soybeans were found to reveal lower antioxidant activity than black soybean (Kumara et al. 2010; Lee et al. 2016, Yusnawan 2016). Therefore, it is of the interest of the present research work to investigate if the black seed coat contributes to relatively higher antioxidant activity. The seeds of Detam 1 and Detam 2 (the black soybean seeds) were partitioned into the whole seed $(\mathrm{H})$, the cotyledon or seed without the seed coat (S) and the seed coat (SC). Each part of the seed was assayed for antioxidant activity measured with DPPH. The result of the present research work depicted the highest antioxidant activity on the seed coat of both Detam 1 and Detam 2 (Figure 5). The seed coat (SC) of Detam 1 and Detam 2 exerted approximately 7.6 times and 6 times antioxidant activity than their cotyledons $(\mathrm{S})$, respectively. It is a new evident that high antioxidant activity of the black soybean was due to the seed coat. For making Tempe and Tofu, the seed coat of soybean is usually discarded. Considering the antioxidant is mainly localized within the seed coat of black soybean seed, therefore, the seed coat of black soybean could be used as a good source of antioxidant. 


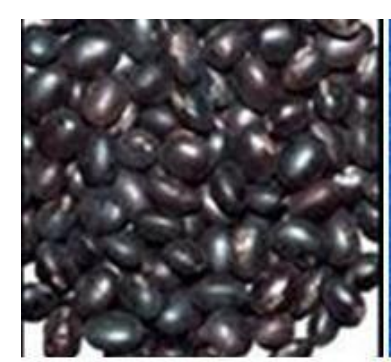

Detam 1 (H)

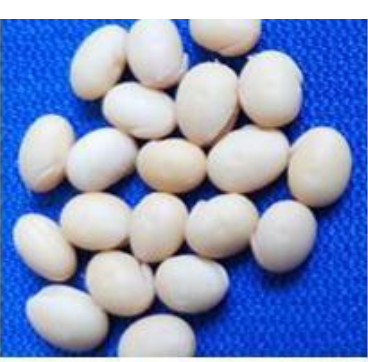

Detam 1 (S)

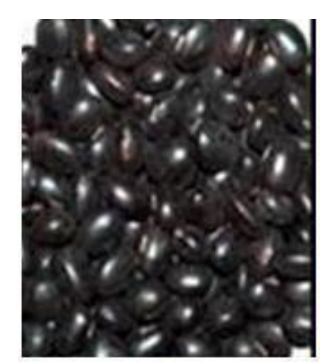

Detam 2 (H)

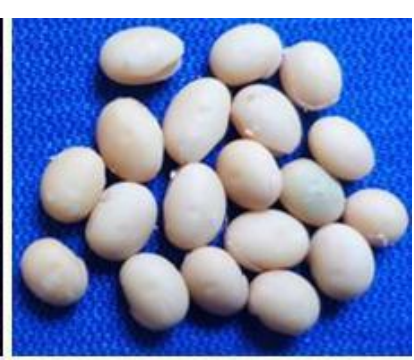

Detam 2 (S)

Figure4. The whole seed $(H)$ and the seed without seed coat, cotyledon(SC) of Detam 1 and Detam 2

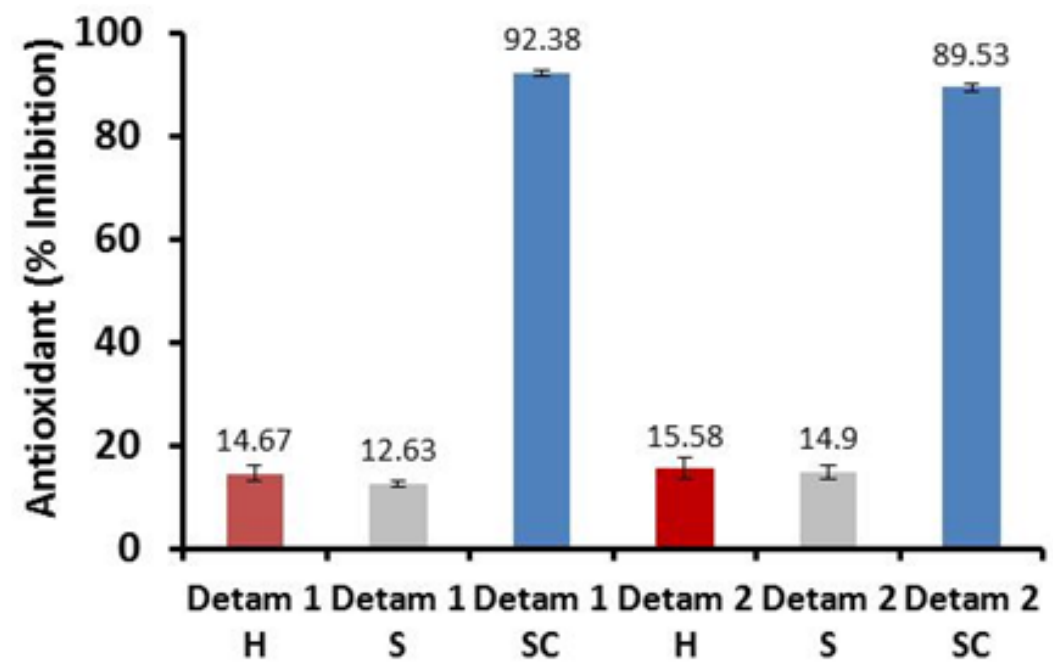

Figure5. Antixidant activities of black coated soybean seeds as measured with DPPH (319.5 $\mu \mathrm{g} / \mathrm{mL})$.

$\mathrm{H}, \mathrm{S}$ and SC are whole seed, seed without seed coat (cotyledon) and seed coat.

\section{CONCLuSion}

Methanolic extracts of Indonesian black soybean seeds contained various amount of phenolic content and showed different antioxidant activities. Black soybean seed did not always show comparably high antioxidant activities. Antioxidant activities positively and highly correlated to the phenolic content. High phenolic content of soybean seed is followed with high antioxidant activity. Thus, phenolic content could be used as an initial indicator to distinguish the degree of antioxidant activities. In black soybean seed, high antioxidant was mainly located within the seed coat. Soybean seed coat could be used as a better source of antioxidant.

\section{ACKNOWLEDGEMENT}

The present research work was funded by Annual Research Funds of Indonesian Legumes and Tuber Crops Research Institute, Indonesian Agricultural Research and Development, The Indonesian Ministry of Agriculture, the Fiscal Year of 2018-2019.

\section{REFERENCES}

[1] Bakhtiari A, Tilaki KH, Omidvar S and Amiri FN. 2019. Clinical and metabolic response to soy administration in older women with metabolic syndrome: a randomized controlled trial. Diabetol Metab Syndr. p. 1-12.

[2] Brand-Williams W, Cuvelier ME and Berset C. 1995. -Use of a free radical method to evaluate antioxidant activity. LWT-Food Sci. and Technol. 28: 25-30.

[3] Doss A, Pugalenthi M and Vadivel V. 2011. Antioxidant activity of raw and differentially processed under- utilized tropical legume Canavalia ensiformis L. DC Seeds, south india. IIOABJ. 2: 27-32

[4] Dajanta K, Janpum P and Leksing W. 2013. Antioxidant capacities, total phenolics and flavonoids in black and yellow soybeans fermented by Bacillus subtilis: A comparative study of Thai fermented soybeans (thuanao). International Food Res. J. 20: 3125-3132. 
In Vitro Investigation on Phenolic Compound and Antioxidant Activities from Methanolic Extracts of Black Soybean Seed

[5] Dudonne. S, Vitrac X, Coutie`re P, Woillez M and Merillon JM.2009. - Comparative study of antioxidant properties and total phenolic content of 30 plant extracts of industrial interest using DPPH, ABTS, FRAP, SOD and ORAC assays. J. Agric. and Food Chem. 57: 1768-1774.

[6] Hossain MA and Shah MD. 2015. Study on the total phenols content and antioxidant activity of essential oil and different solvent extracts of endemic plant Merremia borneensis. Arabian J. Chem. 8: 66-71.

[7] ILeTRI (Indonesia Legumes and Tuber Crops Research Institute). 2016. Deskripsi varietas unggul aneka kacang dan umbi. Balai Penelitian Tanaman Aneka Kacang dan Umbi (Description of improved varieties of legumes and tuber crops. Indonesia Legumes and Tuber Crops Research Institute).

[8] Fidrianny I, Elviana D, Ruslan K. 2016. In vitro antioxidant activities in various beans extracts of five legumes from West of Java-Indonesia using DPPH and ABTS methods. Internat. J. of Pharmacognosy and Phytochem. Res. 2016; 8: 470-476.

[9] Johari MA and Khong HY. 2019. Total phenolic content and antioxidant and antibacterial activities of Pereskiableo. Adv. in Pharmacol. Sci 2019: 1-4.

[10] Khalid S, Ahmad A and Kaleem M. 2017. Antioxidant activity and phenolic contents of Ajawa date and their effect on lipo-protein profile. Functional Foods in Health and Disease 7: 396-410.

[11] Kompas. 2016. Impor Kedelai Mencapai 2,26 Juta Ton (Soybean importation reached 2.26 million ton). http://www.indobic.or.id/indobic/impor-kedelai-mencapai-2-26-juta-ton (accessed 7 March 2017).

[12] Kumara V, Rania A, Dixita AK, Pratapa D and Bhatnagar D. 2010. A comparative assessment of total phenolic content, ferric reducing-anti-oxidative power, free radical scavenging activity, vitamin $\mathrm{C}$ and isoflavones content in soybean with varying seed coat colour. Food Res. Internat. 43: 323-328.

[13] Lee LS., Choi EJ, Kim CH, Kim YB, Kum JS and Park JD. 2014. Quality characteristics and antioxidant properties of black and yellow soybeans. Korean J. Food Sci. Technol. 46: 757-761.

[14] Lee KJ, Lee JR, Ma KH, Cho YH, Lee GA and Chung JW.. 2016. Anthocyanin and isoflavone contents in korean black soybean landraces and their antioxidant activities. Plant Breed. Biotech. 4:441-452.

[15] Malenčić D, Popović M and Miladinović J. 2007. Phenolic content and antioxidant properties of soybean (Glycine $\max$ (L.) Merr.) seeds. Molecules. 12: 576-581.

[16] Malencic D, Cvejic J and Miladinovic J. 2012.Polyphenol content and antioxidant properties of colored soybean seeds from central Europe. J. Med. Food15: 89-95.

[17] Mikulajová A, Takácsová M, Rapta P, Brindzová L, Zalibera M and Németh K. 2007. Total phenolic contents and antioxidant capacities of cereal and pseudocereal genotypes. J. Food and Nutrition Res. 46: 150-157.

[18] Mujić I, Šertović E, Jokić S, Sarić Z, Alibabić V, Vidović S and Ţivković J. 2011. Isoflavone content and antioxidant properties of soybean seeds. Croat. J. Food Sci. Technol. 3: 16-20.

[19] Nam JH, Kang SW, Hong SY, Kim SJ, Jin YI, Kim HS, Yoon YH, Jeong JC, Pan CH, Um BH, Nho CW and Ok HC. 2014. Analysis of the phenolic content and antioxidant activities of soybean extracts from different regions and cultivars. Korean J. Plant Res. 27:610-621.

[20] Parikh B and Patel VH. 2017. Quantification of phenolic compounds and antioxidant capacity of an underutilized Indian fruit Rayan [Manilkara hexandra (Roxb.)Dubard]. Food Sci. And Human Wellness 6: 10-19.

[21] Pertiwi SF dan Nurhidajah A. 2013. Aktivitas antioksidan, karakteristik kimia, dan sifat organoleptik susu kecambah kedelai hitam (Glycine soja) berdasarkan variasi waktu perkecambahan. Jurnal Pangan dan Gizi 04: 1- 8.

[22] Putri DA, Ulfi A, Purnomo AS, Fatmawati S. 2018. Antioxidant and antimicrobial activities of Ananas comosus peel extracts. Malaysian J. Fundamental and Appl. Sci. 14: 307-311.

[23] Rebaya A, Belghith SI, Baghdikian B, Leddet VM, Mabrouki F, Olivier E, Cherif JK and Ayadi MT. 2014. Total phenolic, total flavonoid, tannin content, and antioxidant capacity of Halimium halimifolium (Cistaceae). J. Appl. Pharmaceutical Sci. 5: 052-057.

[24] Sefatie RS, Fatoumata T, Eric K, Shi YH and Guo-wei L. 2013. In vitro antioxidant activities of protein hydrolysate from germinated black soybean (Glycine max L.). Advance J. Food Sci. and Technol. 5: 453-459.

[25] Singh J, Kanaujia R, KumarJ, Singh F, Srivastava AK and SinghNP. 2018. Genetic variability for antioxidant activity and total phenolic content in four major pulse crops. Nov. Tech. Nutri. Food Sci. 1: 1-6

[26] Soedarjo M, Suhartina, Nugrahaeni N, WijanarkoA, Putri DA, and Fatmawati S. 2019. The antioxidant activities and phenolic content of improved soybean seeds varieties of different grain sizes. IPTEK The Journal for Technology and Science (In press).

[27] Stanković MS. 2011. Total phenolic content, flavonoid concentration and antioxidant activity of Marrubiumperegrinum L. extracts. Kragujevac J. Sci. 33: 63-72. 
In Vitro Investigation on Phenolic Compound and Antioxidant Activities from Methanolic Extracts of Black Soybean Seed

[28] Takahashi R, Ohmori R, Kiyose C, Momiyama Y, Ohsuzu F And Kondo K. 2005. Antioxidant activities of black and yellow soybeans against low density lipoprotein oxidation. J. Agric. Food Chem.53: 4578-4582.

[29] Qassabi JSAA, Weli AM and Hossain MA. 2018. Comparison of total phenols content and antioxidant potential of peel extracts of local and imported lemons samples. Sustainable Chemistry and Pharmacy 8: 71-75.

[30] Wu N, Fu K, Fu YJ, Zu YG, Chang FR, Chen YH, Liu XL, Kong Y, Liu W and Gu CB. 2009. Antioxidant activities of extracts and main components of pigeonpea [Cajanuscajan (L.) Millsp.] Leaves. Molecules 14: 1032-1043.

[31] Yusman. 2017. Pertanian di Jepang: Subsidi Pertanian. https://yusmansyah.wordpress .com/2012/09/19/pertanian-di-jepang-3-subsidi-pertanian/ (accessed 7 March 2017).

[32] Yusnawan Y. 2016. The diversity of secondary metabolites in Indonesian soybean genotypes. Biodiversitas 17:704-710.

[33] Țilić S., Hadţi-Tašković Šukalović V, Maksimović V, Maksimović M, Basić Z, Perić V and Maksimović JD. 2011. Antioxidant properties of soybean with black and yellow kernel coat. Proceedings. 46th Croatian and 6th International Symposium on Agriculture. Opatija. Croatia (686-689).

Citation: Muchdar Soedarjo, "In Vitro Investigation on Phenolic Compound and Antioxidant Activities from Methanolic Extracts of Black Soybean Seed" International Journal of Research Studies in Agricultural Sciences (IJRSAS), 2019; 5(12), pp. 1-7, http://dx.doi.org/10.20431/2454-6224.0512001

Copyright: (C) 2019 Authors. This is an open-access article distributed under the terms of the Creative Commons Attribution License, which permits unrestricted use, distribution, and reproduction in any medium, provided the original author and source are credited. 